"we will not resolve tho problems if wo think we have a common purpose. We have two different purposes. We have to see how we are going to serve them and how to bring the consequent results together at some stage. We do not start off from the basic level. This could be one of the most significant contributions to economic planning, if we first accept that principle".

The other, Sir Roy Harrod, Nuffield reader in international economics in the University of Oxford, discussed the relations of economic planning and incomes policy. For a number of years aftor the Second World War inflationary tendencies were certainly due to "too much money ehasing too few goods", and the right way to correct this situation was by monetary and fiscal policies. In more recent times it has appeared, both in Britain and in the United States, that there might be a tendency to inflation, in the sense of rising prices, even in periods when it was perfectly clear that the monetary demand for goods and services was not excessive, as made evident, for examplo, by the economy being slack or depressed. It seemed inescapable that a rise in prices might occur simply because increases of wages, salaries, otc., were being granted in excess of any increase in national productivity and give rise to 'cost-push' inflation.

In the recent period people have become selfconscious about the fact that, in the past seven years, Britain has shown a low growth-rate. The same is also truo of the United States. If Britain is to make a change in her monetary and fiscal policies and try to achieve the growth-rate of which the country is capable, this brings into the forefront the question of how to prevent inflation of the kind that is caused by a 'cost-push'. There is the possibility that a policy of full growth will tend to accelerate claims for higher pay and make employers, who, under a growth policy, will be enjoying good profits, roadier to give them. Hence the idea of a National Incomes Commission.
Tho idea of a policy of planning for economic growth entails problems of formidable dimensions. Such a policy cannot be implomentod without goodwill on the labour side, and to get labour goodwill it will be needful to show that there is some method to secure restraint on the side of distributions of dividend also. But within the field of wages itself there are vast problems. There is the question of relation of wage increases to productivity increases, the question. of the 'wages drift', the question of differentials between grades and between occupations, the proper function of wage increases in relation to the mobility of labour as betweon rising and doclining industries, the problem of leap-frogging, the question of how a trade union leader can relate his thoughts to a national policy without sacrificing, or seeming to sacrifice, the interests of the particular group of workers which he is appointed to look after.

All these interconnected questions have to be looked at in an impartial way without prejudice. Public opinion in certain quarters has been too much inclined to suppose that labour is always to blame when overall wage increases have boon excossive, without appreciating the complexity of the problem. On its side, labour may not always understand the relation between excessive wage increases and inflation. The idea of looking at this complex of problems in a systematic and impartial way presents a great challenge.

In his presidential address to the conference, $\mathrm{Mr}$. Gerald Moxon of United Glass, Ltd., reminded members that the Institute would be celebrating its jubilee in 1963. Its influence over many years in building up good industrial relations deserves to be much more widely known and it is to be hoped that suitable opportunities will present themselves in the coming yoar. It is so long since the Institute appealed for money to extend its activities that the Jubilee Appeal should meet with considerable response.
T. H. Hawkrns

\title{
BONE MARROW THERAPY AND CHEMICAL PROTECTION IN IRRADIATED PRIMATES
}

\begin{abstract}
$\mathrm{D}^{\mathrm{t}}$ URTNG August 15-18 an international symposium on "Bone Marrow Therapy and Chemical Protection in Irradiated Primates" was held in Rijswijk, the Netherlands. The symposium was sponsored by the Organization for Health Rosoarch of the Central Organization for Applied Scientific Research in the Netherlands (T.N.O.), and the Radiobiological Institute T.N.O. acted as host for the meetings. Thoro were 32 participants from France, the Netherlands, the United Kingdom and the Unitod States, of whom 22 presented papers. The main object of tho symposium was to exohange ideas as to the causes of difficultios in tho treatmont of irradiated primates, including human patients, and to discuss future rosoarch plans to overcome these difficulties.

In the session on "Bone Marrow Transplantation in Monkeys", C. Ambrus (Roswell Park Memorial Institute, Buffalo) presonted data on homologous and autologous bone marrow transplantation in rhosus monkeys. Autologous transplantation gave better survival than homologous, but a high percentage of
\end{abstract}

the homologous-treated animals survivod for as long as 24 months with evidence of secondary disease in only one animal. The data showed that there was a marked tendency toward reversal of the chimæric stato in tho homologous-treated monkeys.

R. J. Young (Radiobiological Laboratory, Austin, Texas) reported the results of homologous and autologous transplantation in twenty rhesus monkeys. Autologous transplantation afforded good survival, but there were no long-term homologous survivors. The data showed evidence of secondary disease in homologous animals in which the take of the graft was ascertained by red cell antigens.

The data presented by Mrs. F. Nowsome (University of Tennessee Medical Units, Memphis) showod evidence that homologous marrow after $550 \mathrm{r}$ was more effective $48 \mathrm{~h}$ after irradiation than at $30 \mathrm{~h}$. She reported on heterologous transplants using oynomolgus donors and rhesus recipients with the electrophoretio patterns of hæmoglobin serving as an indication of the take. She concluded that the grafts took but were later rejected. The same results wore 
seen in cynomolgus monkeys treated with homologous marrow. Autologous transplantation in 19 rhesus monkeys was reported by $R$. Schofield (Paterson Research Laboratories, Christie Hospital, Manchester) in which six animals survived for more than 30 days post irradiation. A large number of deaths was attributed to bacteræmia.

L. M. van Putten (Radiobiological Institute T.N.O., Rijswijk) reported that several methods used in mice to prevent or treat secondary disease apparently do not work in monkeys. Preliminary results, however, indicate that the use of fœtal liver shows some promise in this direction. A detailed report of the pathology of secondary disease in primates was presented by $\mathbf{M}$. J. de Vries (Radiobiological Institute T.N.O., Rijswijk), in which he showed striking similarities between this process in monkeys and humans and pointed out their differences with reference to mice. The prominence of secondary disease in the monkeys treated by R.J. Young et al. and those treated by the Rijswijk group was in sharp contrast to the absence of this complication in Ambrus's cases and in cases reported previously by B. G. Crouch (U.S. Naval Radiological Defense Laboratory, San Francisco) and R. R. Overman (University of Tennessee Medical Units, Memphis) and this discrepancy gave rise to much discussion. It was also concluded that much more insight was needed into the reactions of primates on homologous bone marrow transplantation following midlethal and sublethal doses of radiation in view of the adverse results obtained by Mrs. F. Newsome.

There were two papers in a session on the "Immuno. logical Activity of the Primate Foetus". H. E. M. Kay (Royal Marsden Hospital, London) reviewed the knowledge of the development of the lymphatic tissues in the human embryo and presented the results of the administration of foetal liver cells in cases of bone marrow aplasia. $\mathrm{He}$ also reported on preliminary results with fœetus to fœetus transplants in cases of $\mathrm{Rh}$ incompatibility with little evidence of a proliferation of the grafted cells. R. Bangham (National Institute for Medical Research, Mill Hill, London) described his methods of immunizing and sampling monkey fœetuses at various ages. $\mathrm{He}$ obtained evidence of immunological reactivity in embryos as early as 9 weeks gestation.

In the session on Monkey Colony Management, D. B. Gisler (Wright-Patterson AFB, Dayton, Ohio) presented details of a method for determining the age of monkeys from roentgen graphs by measuring skeletal growth and epiphyseal ossification. A. J. Riopelle (Yerkes Laboratory, Orange Park, Florida) discussed the breeding and raising of chimpanzees for biological research with particular reference to radiation studies. Problems of the sanitation of monkeys brought from their natural habitat into the laboratory situation were reviewed by $\mathrm{D}$. van der Waay (Radiobiological Institute T.N.O., Rijswijk). He related experiences with rhesus, cynomolgus, pig-tail and African green monkeys and emphasized the problems connected with parasitism and bacterial infections.

N. Gengozian (Oak Ridge Institute of Nuclear Studies, Tennessee) described the care and handling of the pigmy marmoset for laboratory studies. In addition, he presented preliminary data on the $L D_{50}$ for this species and data on various peripheral blood parameters following irradiation, which suggested that the marmoset is relatively more radiosensitive than other monkeys studied so far. A systemic dermatosis of uncertain ætiology in the rhesus monkey was described by M. J. de Vries (Radiobiological Institute T.N.O., Rijswijk). The disease has proved to be fatal in a number of cases and is postulated to be due to an interference with vitamin A utiliza. tion. Histological examination of tissues showed striking similarity to those seen in $X$-disease in cattle.

In the session on "Human Applications of Bone Marrow Transplantation", N. B. Kurnick (University of California, Veterans Administration Hospital, Long Beach) advocated the storage of bone marrow for all patients undergoing extensive radiotherapy. Re-infusion after the occurrence of aplasia is only occasionally needed, but may in those cases be of great benefit. Evidence was brought forward to show that in this respect man differs markedly from the mouse, since in this animal subtotal irradiation rarely causes dangerous aplasia. J. G. Humble (Wostminster Hospital, London) gave an account of the application of autologous bone marrow suspensions in large volume radiotherapy. This improves the safety of the procedure and once the other risks of large volume therapy (radiation pneumonitis) have been identified, the technique opens new therapeutic possibilities. F. Loeb (Wadley Research Institute, Dallas) discussed the use of stored autologous bone marrow after radioisotopes in high doses in the palliative treatment of malignant tumours and attempts at homologous bone marrow treatment after total body irradiation for leukæmia. The techniques of storage were extensively discussed. J. Ambrus (Roswell Park Memorial Institute, Buffalo) similarly advocated the storage of hæmopoietic cells for patients undergoing chemotherapy or irradiation combined with chemotherapy and discussed in addition a number of experimental studies. G. Mathé (Hôpital Saint-Louis, Paris) summarized his experience with homologous bone marrow therapy in the treatment of radiation accidents and after therapeutic irradiation of patients with leukæmia. From his series of clinical data, man appears to be more radiosensitive than most experimental animals with the $L D_{50}$ at approximately $400 \mathrm{r}$.

In the session on "Chemical Protection of Primates", J. R. Newsome (University of Tennessee Medical Units, Memphis) discussed the results of combined treatment with two different chemicals. The use of both aminoethylisothiuronum (AET) and paraaminopropiophenone (PAPP) had a markedly greater dose-reducing effect than did either compound alone. G. S. Melville (School of Aerospace Medicine, Brooks AFB, San Antonio) presented similar data combining AET with cysteine in rhesus monkeys. He also presented evidence to show that 'Nembutal' enhanced the dose-reducing capacity of these compounds. AET and cysteine were also combined in the protection of monkeys against $800 \mathrm{r}$ by $\mathrm{L}$. van Lancker (University of Wisconsin, Madison). $\mathrm{He}$ concluded that an effective $\mathrm{X}$-ray dose reduction was obtained with these compounds and further that marked cellular regeneration of spleen and bone marrow were evident in protected animals by 30 days following irradiation.

The Proceedings of the symposium, including the discussions, became available on November 1 and can be obtained from the Radiobiological Institute T.N.O., 151 Lange Kleiweg, Rijswijk (ZH), Netherlands, and from Dr. R. R. Overman, University of Tennessee Medical Units, Memphis, Tennessee, U.S.A., at the price of 4 U.S. dollars.

D. W. vaN BEKKUM 